\title{
WE THE POOR MUST ABANDON OUR WHEELCHAIRS AND BEGIN TO WALK UNAIDED: ON AFRICAN AGENCY DISCOURSE
}

\author{
Godwin I Akper \\ Systematic Theology \\ Stellenbosch University
}

\begin{abstract}
After mapping the current notions of African agency discourse, the article suggests a more dialogical approach to the discourse, the partnership notion of African agency discourse. This suggestion is based on the view that African leaders and academics are apparently not yet ready to walk unaided. Therefore, the article proposes a broadened African agency that involves other races. Specifically, it stresses the need for a discourse that goes beyond a black identity as a category for an African agency discourse to be African proper. The essay further suggests that the contribution of the "other" in the discourse should be cherished by black and white discussants.
\end{abstract}

Key words: African agency, discourse, postcoloniality, Westernism, Maluleke, Nadar, Wa Thiag'o

\section{Introduction}

"It is perhaps time that we the poor and powerless abandon our wheelchairs and begin to walk unaided..." (Mbeki 2004:45).

There is a growing dissatisfaction with the current African agency discourse because of the conviction that the discourse itself is merely about "blacks" and "powerless" Africans. So that, even blacks who are currently participating in the discourse do so not as "framers and discussants" but fraudulently as aliens "because what is available to them in the academy is not real power but fraudulent and rented power" (Nadar \& Maluleke 2004:5). In the 21 century, therefore, black African intellectuals on their part are no longer comfortable with the idea of what Tinyiko Sam Maluleke (UNISA) and Sarojini Nadar (UKZN) call "alien fraudsters" (2004:5-17) in the agency discourse. By agency it is meant that "human beings, even the most oppressed, marginalized and seemingly destitute among them, have the potential, possibility and even to act as (moral) agents of transformation and change in their own lives and in the lives of others" (Maluleke \& Nadar 2004:7-8). In a special issue of the Journal of Theology for Southern Africa (no. 120 November 2004) several suggestions are made so that black people could become "framers and discussants" in the agency discourse (see Maluleke 2000:237-245).

The discourse is not only for theologians. African political leaders are also calling for a more viable African agency with various suggestions. One of such suggestions comes from the South African President Thabo Mbeki from whom the first part of the title of this essay is taken. At the $59^{\text {th }}$ General Assembly of the United Nations Mbeki suggests the notion of economic self-reliance as a probable way forward towards a more viable African agent in 
the development of Africa. Mbeki says "it is perhaps time that we the poor and powerless abandon our wheelchairs and begin to walk unaided" (2004:45). To him, all the underdeveloped and developed nations and their people especially the heavily indebted nations constitute what he refers to as the poor. These nations and their people expressed their destitution in the hope that rich and powerful developed nations that Mbeki refers to are going to offer economic and technological support and assistance to the poor and powerless African nations and their peoples to no avail. Since the promises for such support and assistance has not been fulfilled by the rich Western nations, Mbeki, like other Africans of diverse professions, are opting for an African self-reliance. In the light of the above, African academics and their leaders are underscoring the urgent need for an active African agency hence the African agency discourse that has taken a broader dimension to cover all disciplines of life. Truly, as poor and powerless Africans, if we are to become agents of ourselves, we must be willing in the first place to "abandon our wheelchairs and begin to walk unaided" as Mbeki admits (Mbeki 2004:45). But are we ready for such a task?

In this essay I hope to argue for alternative notion of African agency without necessarily becoming an "alien fraudster" in the agency discourse. I hope to argue that the current proposals are good but since black Africans are not ready to "walk unaided" the agency should be expanded to include all "Africans" who live in Africa. By this I mean going beyond "black" identity as a category for African agency. Structurally, I shall first map-up the African agency discourse so that it will become clear why I am proposing alternative notions of agency. Secondly, I shall present my own alternative proposals for a broader African agency.

\section{Early and later Notions of African Agency}

As early as the beginning of the $19^{\text {th }}$ century, it was clear to some African Christian leaders like the South African Jeremiah Mzimba, that for Africans to become agents in their theology, worship life and ministry in Africa, they need at least minimum independence from the West. Mzimba's conviction was that "even the Black man [sic] in Africa must stand on his feet in matters of worship like people in other countries, and not always expect to be carried by the White man [sic] on his back". Mzimba was convinced that it was time for the black man to learn to do things by himself. He argued that "today he [black man] must stand without leaning on anybody except his [sic] God so that the work of God should flourish because the child itself feels it must walk..." (all quotes taken from Maluleke 2000:229). It is a contradiction in terms, as Mzimba saw it, to claim to be an agent of your life and theology but to turn around and depend on others for instruction on how to go about your worship life and theology. Whether Africans at that time heeded to Mzimba's call is another story.

However, in the $20^{\text {th }}$ century it became clear, perhaps due to frustration, to many African theologians that there is no alternative to theological independence from the West. The late Nigerian theologian, Bolaji Idowu made a similar call soon after Nigeria's political independence from Britain that Africa should have her own church and theology. Speaking specifically from the context of his Nigerian church, Idowu criticised the Nigerian church for leaning too much on Western theology and worship style. He asked whether "the aim of religious education in Nigeria was to make Christians or to 'Westernise' Nigerians; whether, in fact, Christianity and 'Westernism' are not synonyms in their evangelistic vocabulary" (1965:1). Seeing that the worship life and practice of Nigerian churches is nothing different from what is obtainable from the West, Idowu asked further whether "what we have [in Nigeria] today is in fact Christianity and not only transportations from a 
European cult the various ramifications of which are designated Methodists, Anglicans, Presbyterians, Baptists, Roman Catholics, Salvation Army, Seventh Day Adventists, and so forth" (1965:1). His point was that there was no reason why Nigerian Christians should clothe their churches with Western theology and style of worship years after independence. Like Mzimba, Idowu thought that it was time for African Christians to begin to mould their own theology relevant to the need and aspiration of the Africans. For him, there has to be an African agent in the process of evangelisation for Africa to have an "African Christianity".

Underscoring the need for an African agent in Christian missions the Gambian born theologian, Lamin Sanneh, speaks of the inconsistency of the Western missionaries' approach to the question of Christianity and culture. He criticises the Eurocentric approach to African cultures and argues that even those missionaries who attempted to dismantle African cultures as a way of penetrating African hearts and society with the Gospel did not abandon their own cultures. Rather, they preserved and promoted such cultures to the extent of presenting the Gospel in the context and values of their own cultures in Africa. He notes the:

deep logical inconsistency between the claim that culture is independent of Christianity on the one hand, and, on the other, that the religion is reducible to its cultural forms, is connected to an unexamined assumption about the intrinsic innocence of indigenous cultures whose primitive purity has been contaminated by imperialist missions. With indigenous society's culture and contact viewed as detrimental, while in the West such contact is proof of religion as cultural phenomenon, while in its Western origins the religion is an idealized myth which evaporates once it is demythologized" (1993:15).

Sanneh asserts that African Christians need to "transcend this approach to the subject in order to deal with the phenomenon of world Christianity and with the extraordinary movements of cultural renewal taking place under its shadow" (1993:15). This is because "it would not be possible to uncouple religion from culture. On the contrary, Christianity has entered a renewed destiny with its affirmation of cultural particularity, and vice versa" (1993:15). African Christians should take advantage of this positive development by actively participating in the inclusion of culture in the contemporary religious discourse. Sanneh claims that modern African Christians who are Christians today belong to particular brand of Christianity, one "mediated to them by the West", but as Christianity continues to penetrate the nooks and corners of Africa and African culture specifically, its success has been and will continue to be on its assimilation into the local idiom (1993:16). No one else can do a better job of assimilating Christianity in the local idiom than Africans themselves.

The Ghanaian theologian, Kwame Bediako, also argues that even the second century patristic theologians like Clement of Alexandria and Tertullian, among others, were successful in their theological career and task based on their assimilation of Christianity and theology in the then African cultures and values (1992). His Christianity in African Culture: the Renewal of a non-Western Religion (1995) explores the central role African cultures play in the rapid spread of Christianity on the continent which is why Christianity has become an African religion after being stripped off of all the shackles of Eurocentrism. Bediako like Sanneh makes the point that where Christianity strives in Africa, it is because of its "African presence" (Maluleke 2000:229), thereby, underscoring the need for African agency in Christian missions and theology.

The Kenyan writer, Ngugi wa Thiag'o, argues for African agent in literature. He expresses disappointment over the dominance of English and other European languages over African, Asian and South American languages in literature departments worldwide. The former exiled writer says that in the 1960 s when he was still a student, "most of the 
[literature] departments [in African Universities] were largely confined to the languages of Europe and within Europe to the literature produced by the nations of that languages" (1993:7). With this kind of situation "it was possible all round to graduate with a literature degree in any of the European languages without ever hearing of Achebe, Lamming, Tagore ...writers from that area of the globe that has come to be known as the Third world" (Wa Thiag'o 1993:7). This kind of imperialism was not limited to European universities. Wa Thiag'o was "horrified" when in 1967 he returned from Leeds University to Kenya to "find that the Department of English was still organised on the basis that Europe was the centre of the universe" (1993:8).

Europe's interest is mainly capital accumulation, and imperialism was the most effective means of accumulating that wealth with much ease. Education and so-called civilisation are vehicles through which Europe marginalised the so-called Third World countries' cultures, values, languages, people, media etc, Wa Thiag'o maintains. In every sector of life these countries and their people have Europe to lead them in telling them who they are, what their cultures and religions are, how they can develop, how many they are, among other things. They are simply not agents in their so-called development and civilisation process. Therefore, it is needless to say that "the encounter between English and most so-called Third World languages did not occur under conditions of independence and equality" (Wa Thiag'o 1993:31), neither was the encounter of Christianity - through the Portuguese, the French and the English - with the poor and the powerless people of the socalled Third World neutral and innocence (Wa Thiag'o 1993:31). These Europeans brought to Africa the Bible and the sword (Wa Thiag'o 1993:31). If it was the gun, Wa Thiag'o asserts, "which made possible the mining of this gold and which effected the political captivity of their owners, it was language which hold captive their cultures, their values, and hence their minds" (1993:31). Wa Thiag'o says that "Economic and political control can never be complete or effective without mental control. To control a people's culture is to control their tools of self-definition in relationship to others" (1986:16). For colonialism, says Wa Thiag'o, Economic and mental control involved two aspects of the same process namely, "the destruction or the deliberate undervaluing of a people's culture, their art, dances, religions, history, geography, education, orature and literature, and the conscious elevation of the language of the coloniser" (1986:16).

Therefore Wa Thiag'o is convinced that a people cannot lay claim of complete independence if its language and culture is still captive by the language and culture of the colonial overlords. Full independence takes place when languages and cultures as well as the mind-set of the colonised are free from influence and control of the colonial (oppressor) languages and cultures. However, for this to take place the cultures, values, minds, religious life, and politics of the poor and powerless are to engage those of the Western rich and powerful countries and their owners must be agents in that engagement. Ngugi Wa Thiag'o therefore calls on the people of the so-called Third World to take ownership of their languages, values, politics, media, religious life, and culture, and promote them through literature.

For the above stated reason, Wa Thiag'o insists that as long as our education departments are still programmed on the basis that Europe is the centre of the universe, our values and languages, politics and economics, cultural and religious lives will continue to be suppressed by the Western scholars upon whom we seem to depend (Wa Thiag'o 1986 \& 1993). In order to secure effective independence from the West, Wa Thiag'o stresses the need for a shift in methodological starting point of African scholars and curriculum developers in African universities. He states emphatically that it is important that Africans look at the starting point of their interaction: from what base are they looking at the world 
and their situation? Is it from a Eurocentric perspective or is it from an Afrocentric point of view? (Wa Thiag'o 1993:8,9).

This conviction was echoed in South Africa in the dark days of racial oppression in South Africa, by the famous South African black theologian, Itumaleng Mosala who questioned the sincerity of Black theology's exegetical starting point. Mosala supported the idea of Black theology as a weapon of struggle for the poor and oppressed. But he criticised Black theology's starting point. He argued that the fact that Black theology "exposed the cultural assumptions of White theology" showed its link with White values and so, it "exploded the [same] myth of rational objectivity in theology" as White theology (1986:176). Mosala was not comfortable with the fact that while "black theologians condemn white people's view of God and Jesus Christ as transcending political ideologies, they inconsistently maintain a view of Scripture similar to white people: Scripture as an absolute, non-ideological Word of God which can be made ideological by being applied to the situation of oppression" (1986:177-178). Mosala then asserted that for Black theology to become a material force of struggle for the poor and oppressed it needed to depart from white theological starting point. In other words, while Black theology advocated for black agents in the struggle by developing a relevant theology for the blacks oppressed, it ambiguously borrowed the language, cultural values and religious starting point of the oppressors.

To be real agents in the time of struggle blacks were to look at the situation of the oppressed, the material condition of the oppressed, and the cultural values of the poor and then read the Bible from the perspective and stand point of the poor and oppressed but not from the assumption of the white oppressors. Similar to the aspirations and convictions of Wa Thiag'o concerning literature, Mosala in Black theology argued that the "social, cultural, political and economic world of the black working class and peasantry constitutes the only valid hermeneutical starting point for a Black theology of liberation" (1986:181).

Boesak, like Wa Thiag'o, speaks of the situation where "the colonial victories were God's victories, and the land, as well as the wealth within it, was just as easily seen as a right, a gift and a reward: God's recompense for a faithful, pioneering people who brought with them the Gospel of salvation for the savages of an unsaved continent and who were, in fact, God's own people..." (2004:9). In the light of these, seeing the biases of the imperial Christianisers, Banana, while conceding that God indeed do speak to mortals, he unavoidably considered it nonsensical for a group of religious people (like Israel) in a particular period in human history to deem themselves fit to give legitimacy to a certain matter like the canon of Scripture, or for such religious people to proclaim their land as holy and other's profane; also to regard themselves as agent of God's revelation and Christianisation of the world while the rest of the world's population can only learn of God's self disclosure (revelation) from the experiences of such a self-imposed people of God. Therefore, Banana did not see any reason why Africans should consider Palestine as a holy land and his country Zimbabwe as not (1993:19). What grounds are there to think that the water from the Jordan River is of more importance than that from Zambezi River? (Banana 1993:19). This implies that the cultures of the so-called Middle East and those of Africa, Asia, the Americas and Europe, together with their people and religions as well as their prophets are equally agents of God's revelation with equal level of legitimation (Banana 1993:19-21). Hence, Banana suggested that the present Bible should be expanded to include the religious shrines, traditions and prophetic voices of the peoples of Asia, Africa, Europe and the Americas (1993:21). Again the owners of these places are to be agents of the "re-writing" of the Bible in order to avoid once again the exclusion of their 
people and cultures from being of revelatory importance. The urgency of African agency in the process of rewriting the Bible is emphasised.

The African-American theologians, Glenn Usry and Craig S Keener write about the plot of Western scholars to subjugate Africans in order to promote the supremacy of their Western comrades in their research and literary works. They refer to a recent "notorious book" The Bell Curve in which "some White American researchers argued that Blacks on average have lower IQ scores than Whites because of their genes" (1996:21). Compare to the great European philosopher, GWF Hegel (1965), the authors of The Bell Curve are generous in their assessment of blacks. Boesak cites Hegel as saying:

If you want to understand [the Negro], you must abstract all elements of respect and morality and sensitivity [for] there is nothing remotely humanized in the Negro's character... Africa proper, as far as history goes back, has remained for all purposes of connection with the rest of the world, shut up. It is... the land of childhood, which lies beyond the days of self-conscious history, is enveloped in the dark mantle of Night.... In Negro life that consciousness has not yet reached the realization of any substantial objective existence - as for example God, or Law in which the interest of man's volition is involved, and in which he realizes his own being. [...] It is the essential principle of slavery that man has not yet attained self-consciousness of his freedom, and consequently sinks down to a mere Thing - an object of no value. Among Negroes moral sentiments are weak, or more strictly, non-existent (2004:10).

If these scholars were to rewrite the Bible they will probably exclude Africa, arguing that blacks' IQ is not well-developed to receive and comprehend God's revelation. This explains why the call to re-write the Bible is, consequently, a call for African presence in the composition of the Bible, arguing that African people and their cultures were also, in fact, agent of God's revelation. This means that Africans must be agents in the process of re-writing the Bible in order for Africa to be included in the contents of the Bible as God's agents of revelation.

Since Africans (Banana 1993 \& York 1995), the poor and oppressed (Mosala1986, 1989; cf Maluleke 1996), women (Oduyoye 2001), and the colonised (Dube 1997, 2000) were not agents in the composition of the Bible, the Bible is regarded by many Liberation, Feminists, Afrocentric and Postcolonial biblical scholars and theologians as a Western imperial book. Dube does not hesitate to declare that "To read the bible as a Motswana African woman is to read a Western book" (1997:11). She believes that the designation "biblical Christians" refers to "white western believers" - though there were African "biblical believers" like the Ethiopian eunuch in Acts 8:26-38 - and the term "pagans" refers to "all non-Christian Africans" (Dube 1997:11). Dube argues that the imperial tendency to subjugate and suppress the Africans did not end with the white Pharisees in the early church, saying that it is also "a familiar drama of nineteenth-twentieth century imperialist history upon all non-Christian Africans" (Dube 1997:11). Like the biblical Pharisees who referred to the gentile Galatians as "foolish Galatians" (Gal 3:1), the nineteenth, twentieth, and now, the twenty-first century neo-colonists would stop at nothing to portray the West as the centre of all cultural good. Also, as a centre with a supposedly redemptive impulse while it relegates all other cultures to the project of civilisation, Christianising, assimilating, and developing (Dube 2002:104). Dube writes: "The colonial approach constructed both the colonizer and the colonised to accept their given places in the rhetoric of colonizing" (Dube 2002:104). Therefore, even the "criminal appropriation of the land, the genocide of the Khoi and the San, the destruction of the African peoples as a whole as well as their cultures, the enslavement of people, indigenous and imported - all 
this was not only permissible. It was unavoidable and necessary for the colonial project and therefore the will of God" (Boesak 2004:10-11). So that Africans were and are being "coerced" (Mugabe 2004) to accept this offer of the knowledge of divine will and intentions. The fact that the colonists were agents in the transmission of this so-called knowledge of divine will, they presented and continue to present it in such a way that it simply favours the imperial interest of the powerful West. Dube speaks of how the African situation, in relation to the powerful and influential West, is being presented to the world by the Western controlled media. She says that Africa on TV and movies, "it is represented by poverty, disease, war, or wild animals" while USA and Britain are represented by "White House" and "Westminster's golden Parliament", all because the media is controlled largely by the West. This, among other things, indicates to (black) Africans that they must be agents in any discipline and sphere of life that in which they are involved. Therefore Africans are seeking that their presence be noticed in spheres of life as Maluleke (1995, 1996, 1998, 2000) and Gerald West (1991, 1992, 1997, 1999, 2002, 2004; cf. Akper 2005 \& 2006), among others stress in their works, calling for African agent. But these notions of agency are either not broad enough to include the agency of African women (Maluleke $1996,2000,2004$ ) or are simply another "subtle and more vicious form of marginalization wherein this discourse is but one more space where the powerful dismiss the crushing pain of oppression [Africans] this time by benevolently, hastily, easily and even deceptively calling it agency" (Maluleke \& Nadar 2004:3). Hence, the following section will briefly discuss the "next stage" (Maluleke \& Nadar 2004:3) in the agency discourse that goes beyond what is obtainable in the past to the one where African men and women are considered real actors in the agency discourse.

\section{The 'Next Stage' in the African Agency}

The fervent calls for African presence in all areas of human endeavour may create the impression that Africans were and are passive victims of marginalisation, domination, and economic and intellectual neo-colonisation. However, there are very impressive arguments these days (by Africans) that this has never being the case. The Kenyan born theologian, John Mbiti argues persistently that it was the African Traditional Religions that opened the minds of the Africans to the easy reception of Christianity in the formative years of their encounter with Christianity (see Mbiti 1970 \& 1972). Lamin Sanneh (1989 \& 1995) and Kwame Bediako (1998 \& 2000) also argue that the rapid spread and survival of Christianity on the continent has been and will continue to be as a result of its assimilation in the local idiom. This means that the presence of African indigenous languages as agent for the spread of the Christian gospel is responsible for the rapid Christian presence on the continent. Maluleke makes the point clear that "African theologians are no longer satisfied with assumptions that Africans are passive victims in either the missionary or the colonial process". He further says that "many theologians have realised that apartheid and oppression cannot and does not have the last word on the reality of the oppressed and marginalised black peoples" (2000:237). The post-reconstruction theologies of the South African Charles Vicencio (1992) and that of the Kenyan Jesse Mugambi (1995), developed out of their dissatisfaction with the Exodus metaphor of the Black theology's liberation praxis (see Maluleke 1995, 2000), are new forms of African agency in theology and missions. From the tradition of hermeneutics, Gerald West for the past decade has been arguing that the encounter between the Western missionaries and the African indigenous people has been that of a "transaction" where the Africans received the Bible and Christianity in exchange 
for something more than the land: their culture, religious values that impact on the Bible and Christianity (see West 1995, 1997, 2002 \& 2004).

The arguments against these forms of African agency are that, frantic and voluminous as they may be, those forms of agency are yet to take full note of the ideological and hegemonic issues that are crucial to the agency discourse (Maluleke \& Nadar 2004:13). "Black and women participants in the agency discourse need to take cognisance of the fraudulence of their power, the fragility of their agency, as well as the possibility of their subtle abduction into a discourse of control" (Maluleke \& Nadar 2004:13), especially as a mere presence of black and women faces in the agency discourse will not necessary "tilt the ideological and hegemonic scales. If anything, it might result in making hegemony that look nobler and less harsh" (Maluleke \& Nadar 2004:13). Here lies the imperative of the "next stage" in the African agency discourse: the one where the poor and marginalised groups, educated and uneducated African women and men are active participants in the dismantling of ideological and hegemonic system that seek to sustain their marginalisation.

The "next stage" of the agency discourse has what can be described as "rules of engagement" in order for it to meet its desired objective to change the existing condition of ideological and hegemonic forms of domination. The "rules of engagement" are outlined by Maluleke and Nadar (2004:16-17). Firstly, those who engage in the discourse must do so in such a way that it is "truly about Black male and female agency, in its own right, for its own sake" (Maluleke \& Nadar 2004:16). Secondly, Whites and male intellectuals who participate in the discourse are welcomed but only if they participate with a genuine intention to change the ideological hegemony that seeks to protect and cover the interest and evils of their comrades. Therefore, they must do more than just declare their identity as white intellectuals in solidarity with black Africans where they pay nothing more than lips service to blacks; while in effect, they subtly contribute to the sustained domination of black Africans, male and female. Thirdly, that those who engage in the discourse must realise from the onset that African agency is not a definitive event about specific people at a particular time within certain circumstances. It is an enduring project about and for black male and female. Fourthly, black male and female intellectuals involved in the discourse must be aware and ready to withstand the danger of being abducted by the whites that are involved in the discourse, so that, black male and female Africans do not engage in the discourse fraudulently as aliens. In the "next stage" of agency discourse, therefore, it is important to take cognisance of the above "rules of engagement".

It is important to give attention to African female agency in the "next stage" discourse for the reason that the discourse in the past has been predominantly a male discourse as Maluleke and Nadar observe. African women theologians also observe that right at the beginning of the African agency discourse, "just as Western theologians tend to ignore the social cultural locations of African women, African men theologians tend to generalise about Africa without including the experience of women" (Oduyoye 2004:72). This implies that "even when the Bible is read with reference to African culture, women tend to remain invisible, or worse, they are regarded as the source of all that is negative" (Oduyoye 2004:72). This development impels on African men to be critical of their engagement in the discussion of African agency in the "next stage" so that it is not once again another subtle way of covering up the past evils of African men under the pretext of solidarity and speaking "with" and about African women and their situation. The inclusive methodology adopted by African women should guide all Africans involved in the agency discourse.

The postcolonial theology of Musa Dube, for example, attempts an inclusive African agency discourse. While her postcolonial theology is done from an African feminist 
perspective, it seeks to include all Africans and, to some extent, all the marginalised people of the so-called Third World. Frank England says "postcolonial studies focuses on the power configurations that have resulted from the subjugation of indigenous people by colonizing powers, and cultural realms are still determined and informed by colonialism, as well as those places where a radical break with a colonial heritage has been made, or, perhaps better, attempted" (2004:89). If this description of postcolonial studies is anything to go by, agents of postcolonial criticisms should preferably emerged from the colonised groups. It is therefore remarkable that Dube takes an inclusive approach to postcolonial biblical studies. She argues for an inclusive critique of the imperial import of biblical origins, arguing that "Christian texts point beyond their origin, inviting their readers [male and female] to act them out in history cross-culturally" (1997:11). Therefore she proposes, from a feminist perspective of course, a post-colonial "strategy that strives to understand how the ideology [crucial issue in the agency discourse] of various ancient imperial settings informed biblical texts; that scrutinizes the power relations propounded by mission texts in their instructions of different cultures and people... (1997:11). In her study on reading and teaching Jesus' miracles of healing in a context of Aids, Dube does not seek to represent the voices of the marginalised victims of Aids (male or female). She allows them the space to study, scrutinise, and apply the chosen text to their specific existential situation of Aids (see Dube 2002:121-133). What readers read is not Dube's report about the reading strategies of the community of Aids victims. But the actual voices of the victims especially how they understand Jesus' healing miracles in their experiences as Aids victims. Here is an example of an agency of the marginalised group that is not too "fraudulent" (Maluleke \& Nadar 2004:5-17), though it can still be likened to what Maluleke and Nadar call "survival" kind of agency. After all, the discourse about African agency is more or less a "survival" tactic to resist domination, both from "outside" and from "within". The Aids victims like the oppressed in the Bible (cf Mosala 1989) did not write the report on their reading strategies. One hears their voices through the printed work of a healthy well-trained biblical scholar, similar to the situation that exists between the "ordinary reader" and socially engaged biblical scholar (Akper 2005).

The South African biblical scholar, Madipoane Masenya, questions the reality of African agency in contemporary South African Old Testament scholarship. In attempt to answer the question: is white South African Old Testament scholarship African? Masenya describes as "disturbing" the pains that scholars have to take to define who an African is whereas it was crystal clear during the apartheid era who an African was, a designation cherished then by no one including the black Africans because of its derogatory import (Masenya 2002:3-4). The female biblical scholar finds it "confusing" that in an attempt by Africans to rediscover what they "lost or were made to lose" those "who had the privilege to define us negatively, would now want to pose as though they were one with us and/or have been with us all along" (2002:4). Such a move, Masenya argues, "will not advance our attempt at self-discovery, selfaffirmation as an African people in any way" (2002:4). Her suspicion is that the claim to be "African" in the white South African biblical scholarship is opportunistic, and therefore, capable of perpetrating the same act of marginalisation and oppression this time intellectually - a view-point clearly expressed by Maluleke and Nadar (2004:5-17). She challenges the white South Africans "who 'correctly' want to claim to be 'African' all of a sudden because they argue that they were born and bred on the African continent" to answer the question: "when did these white South Africans become aware that they were born in Africa?" (2002:4). Furthermore, "if they are Africans, how serious do they take the African context(s) in their scholarship? For those white Old Testament scholars who are, all of a sudden, attempting to take the African contexts into account in their scholarship, we ask: what is 
prompting them to do it in present day South Africa?" In a related question she asks: "is it because of the national pressure to transform? Are they now aware that it is tragic to do Western theology/Old Testament studies in an African context without taking the needs of African people in different African contexts seriously?" (2002:4).

The sincerity of white South African scholars "correctly" owning Africa and her contexts is further questioned by Masenya on the ground that what they offer to their black South African students is "ivory tower" Western theology, "detached from the real life situations of people on the ground" (2002:5). In addition, she asserts that South African white scholars are more comfortable with European and Euro-American scholars than their African colleagues. Her example is the frequency with which they invite mainly European scholars as "visiting professors at universities that are in an African context: South African universities" (Masenya 2002:5). With the above stated situation, Masenya does not think that white South African scholarship (including Old Testament) is African. Therefore, it cannot and it is not intended to be agentic African intellectual discourse.

Since it is not the purpose of this essay to critically evaluate the above exposed notions and discontentment with African agency, I shall proceed to discuss the question raised earlier in the introductory part of the essay namely, are black Africans on their part ready to "walk unaided"?

\section{On Walking Unaided: How ready are Africans?}

It is clear from the foregoing discussion that neither the proponents of the early notions of agency nor the later, and now, the "next stage" notions of African agency have shown that they are ready to walk unaided. While several calls are made for Africans to begin to feel capable of solving their problems in their own African way, these African academics and political leaders still lean on the back of Westerners in order to make these calls for independence from the West. Jeremiah Mzimba, one of the earliest Africans to call for African agent in missions and theology had to be trained by the West, a kind of education that was later to be condemned by Wa Thiag'o namely, an education structured on the basis that Europe is the centre of the universe. Like Mzimba, the Nigerian Bolaji Idowu too had to lean on the back of imperialists to have his book $A$ Call for an Indigenous Church published and the contents properly and widely disseminated. This book was published in London. As small as it is - less than one hundred pages - it has never been published in Africa, let alone by an African publisher. What is the implication of this? The implication is that Africans have to lean on their Western overlords-turned colleagues in order to be heard by their own African comrades and others. Perhaps, there was no African printing press at Ibadan and other places in the West African sub-region, where Idowu could have published this ground braking book. However, not even the emergence of University Press Limited in Nigeria and in other African countries has helped matters. The present criteria set by African scholars themselves rates international publications higher than regional (local) publications. Thus, young African scholars wanting to be promoted would patronise Western journals and publishers. This also shows that African scholars on their part are not yet ready to walk unaided though some of them may want to walk independently of the West.

Politically and economically too, it appears Africans are not yet ready to walk on their own. While President Mbeki was making the call for African poor nations and peoples to abandon their wheelchairs and begin to walk unaided he was in New York. The most disappointing fact is not that he made the call, but that the frustrated Mbeki painted a picture of a people destitute and frustrated that their pleas are falling on deaf ears while still saying that it is time for this same people to stop begging. There in New York at the 
headquarters of the United Nations, a "poor" African President had to call on his compatriots to learn to live on their own before the rich and mighty nations. One can see yet another dilemma here: one that even the call for us Africans to walk unaided has to be made in the West, and before the neo-imperialists nations.

The Nigerian experience under President Olusegun Aremu Obasanjo, a one time Chairman of African Union, is another example that shows the un-preparedness of African leaders to abandon their wheelchairs. If the reports of local Nigerian newspapers like the Vanguard, Guardian and ThisDay Nigeria are anything to go by, Obasanjo spent more hours in the West in his first four years in office (1999-2003) than in Nigeria, his own country. The purpose of his travels was to canvass for a debt-buy-back. When he finally won the bargain, his country had to part with 12 billion USA Dollars at a time Nigerian labour was on strike for exorbitant increase in pump fuel prices. Not only that, mass retrenchment of Federal Civil Servants followed. Then, the sell out to foreign coreinvestors of all Federal Government establishments followed. All these in the name of "reforms" demanded by the rich European nations as a condition for the so-called debt relief. Nigeria, like most African countries, though far from being called a developed nation it is forced into operating an economy of the developed rich European nations. To me, the above-described situations show that African scholars and their leaders will have to wait for a while before they could attempt walking unaided.

However, the realisation of the urgent need to walk unaided is in order. But certain things need to be put in place before Africans could think of walking unaided. Until that is done, diplomacy, it seems to me, is the best available option in dealing with the West while still being very conscious of the fact that we Africans must start walking on our own without delay. This calls for an alternative notion of African agency discourse. I dare to suggest below a move towards a more viable African agency.

\section{Towards a more viable African Agency}

Efforts made by African scholars toward African agents in scholarship and development are commendable. What is needed now is a broader and step-by-step approach towards agentic African agency discourse. The next step to take, one could suggest, is to adopt a new strategy for encountering the West namely, to engage the West and Westerners; all those regarded as "whites", in our discussion and effort to emancipate our "own" via the academia. This time, it shall not be as alien fraudsters, but as partners. In partnership, the parties involved contribute to the achievement of the desired goals. In the African agency discourse, therefore, black male and female discussants should deliberately invite white discussants to contribute what they have - be it the whiteness that is needed for a publication to be rated high or a university to be rated as best world research university - on the African soil. Of course, there must be checks and balances. As long as the whites do not dominate the discourse and the discourse itself is not merely about blacks and their situation; also, not a mere academic exercise for the purposes of attracting research grants and for promotions, it is still a viable African agency discourse. Through this process, black Africans shall soon hold their own by hands and aid them to walk. The white discussants too, through this process of partnership with their "other", will soon realise that both whites and blacks are constituted by each other through their works. The perceived sense of alienation of the whites by the blacks and vice versa shall hopefully be reduced with time through interaction, owning, deliberation and identification with each other as they seek to address issues and problems that affect them. Both black and white Africans should long for the manifestation of such a situation. 


\section{BIBLIOGRAPHY}

Akper, GI 2005. The 'Ordinary Reader' in Gerald O West's Hermeneutics. Scriptura: International Journal of Bible, Religion and Theology in Southern Africa 88:1-13.

Akper, GI 2006. From Multiculturality to Interculturality? Locating the Ongoing African Agency Discourse in the Debate. Scriptura International Journal of Bible, Religion and Theology in Southern Africa. 91:1-11.

Banana, CS 1993. The Case for a New Bible. In: Cox, LJ, Mukonyora, I and Verstraelen, FJ (eds.) 'Re-writing' the Bible. The Real Issues. Zimbabwe. Mambo Press:17-32.

Bediako, K' 1992. Theology and Identity: The impact of Culture upon Christian Thought in the Second Century and Modern Africa. Oxford: Regnum.

Bediako, K 1998. The Doctrine of Christ and the Importance of Vernacular Terminology. International Bulletin of Missionary Research 22(3):110-111.

Bediako, K 2000. A Half-Century Christian Thought: Pointers to Theology and Theological Education in the next Half-Century. Journal of Christian Thought 3(1):5-11.

Boesak, A 2004. Truth Crushed to Earth will rise again: African Christian Theology in South Africa - Looking back, in Conradie, E. (ed.) African Christian Theologies in Transformation. Stellenbosch: EFSA:9-29.

Dube, M 2000. Postcolonial Feminist Interpretation of the Bible. Chalice Press.

Dube, M 2002. Healing where there is No Healing: Reading the Miracles of Jesus in an Aids Context. In: Phillips, GA \& Duran, WN (eds.) Reading Communities. Reading Scripture Essays in Honor of Daniel Patte Harrisburg: Trinity International: 121-133.

Dube, M 2002. Postcoloniality, Feminist Spaces, and Religion, in: Pui-ian, Kwok \& Donalson, LE (eds.). Postcolonialism, Feminism, and Religious Discourse. New York.London: Routledge:100-120.

Dube, Musa 1997. Toward a Post-Colonial Feminist Interpretation of the Bible. Semeia 78:11-26.

England, F 2004. Mapping Postcolonial Biblical Criticism in South Africa. Neothestamentica 38(1):88-99.

Kato, B 1975. Theological Pitfalls in Africa. Kisinmu-Kenya: Evangel Publishing House.

Keener, CS \& Usry, G 1996. Black Man's Religion: Can Christianity be Afrocentric? Downers Grove: InterVarsity Press.

Maluleke, TS \& Nadar, S 2004. Alien Fraudsters in the White Academy: Agency in Gendered Colour. Journal of Theology for Southern Africa. (November) 120:5-17.

Maluleke, TS \& Nadar, S 2004. The Agency of the Oppressed Discourse: Consciousness, Liberation and Survival in Theological Perspective. Journal of Theology for Southern Africa (November) 120:2-4.

Maluleke, TS 1996. Black and African Theologies in the new World Order: A Time to Drink from our own Wells. Journal of Theology for Southern Africa 3-19.

Maluleke, TS 2000. A Quest for a Historical Quest for a Black Presence that "Walks" in Denis, P (ed.). Orality, Memory and the Past. Listening to the Voices of Black Clergy under Colonialism and Apartheid. Pietermaritzburg: Cluster Publications: 229-250.

Maluleke, TS 2000. The Rediscovery of the Agency of Africans. Journal of Theology for Southern Africa 108:19-38. 
Masenya, M 2002. Is White South African Old Testament Scholarship African? Bulletin for Old Testament Studies in Africa no 12 (May), 3-8.

Mbeki, T 2004. Address at the $59^{\text {th }}$ General Assembly of the United Nations. New African No. 434: 44-45.

Mbiti, JS 1970. Christianity and African Traditional Religions. The International Review of Missions, LIX, 236:439-440.

Mbiti, JS 1972. Some African Concepts of Christology. In: Voicedom, S (ed.) Jesus and the Younger Churches. London: SPCK: 51-62.

Mosala, IJ 1986. The Use of the Bible in Black Theology in Mosala, IJ and Tlhagale, M (eds.) The Unquestionable Right to be Free. Johannesburg: Skotaville.

Mosala, IJ 1989. The Use of the Bible in Black Theology. Grand Rapids: Eerdmans.

Sanneh, L 1989. Translating the Message: The Missionary Impact on Culture. Maryknoll: Orbis.

Sanneh, L 1993. Encountering the West: Christianity and the Global Cultural Process. Maryknoll: Orbis.

Wa Thiag'o N 1986. Decolonising the Mind. The Politics of Language and African Literature. Among other places. Nairobi: Heinemann.

Wa Thiag'o, N 1993. Moving the Centre. The Struggle for Cultural Freedoms. Among Other Places. Nairobi: East African Educational Publishers.

West, GO 1991. Biblical Hermeneutics of Liberation: Modes of Reading the Bible in the South African Context. Pietermaritzburg: Cluster Publications.

West, GO 1992a. Recovering the Suppressed Past and Reconstructing the Future: Historical Consciousness, Biblical and Theological Liberation Hermeneutics. Unpublished Paper. Human Sciences Research Council, Center for Research Methodology, Pretoria.

West, GO 1992b. Some Parameters of the Hermeneutical Debate in the South African Context. Journal of Theology for Southern Africa, 80:3-13.

West, GO 1997. On the Eve of African Biblical Scholarship Trajectories and Trends. Journal of Theology for Southern Africa, 99:99-115.

West, GO 1999a. The Academy of the Poor: Toward a Dialogical Reading of the Bible. Sheffield: Sheffield Academic Press.

West, GO 1999b. Local is Lekker, but Ubuntu is Best: Indigenous Reading Resources from a South African Perspective. In: Sugirtharajah, RS (ed.) Vernacular Hermeneutics. Sheffield: Sheffield Academic Press: 37-51.

West, GO 2002. The Bible as a Bola among the Foundation of African Biblical Apprehensions. Journal of Theology for Southern Africa, 112:23-37.

West, GO 2004. The Open and Closed Bible: The Bible in African Theologies. In: Conradie, E (ed.) African Christian Theologies in Transformation. Stellenbosch: EFSA: 162-180.

York, GL 1995. Biblical Hermeneutics: An Afrocentric Perspective. Journal of Religion and Theology, 2(2):145-158. 